I. O. Kuzo

\title{
Serrated polyps as precursor lesions of colorectal cancer: current status and future directions. Mini-review
}

\author{
Zaporizhzhia State Medical University
}

Key words: Colonic Polyps, Colorectal Cancer, Histology, Mutation, Adenocarcinoma.

Early diagnosis of colorectal cancer (CRC) is a very urgent problem, since this disease has second place among women and the third one among men in the structure of cancer pathology. According to recent data, CRC should be considered as a heterogeneous multifactorial family of diseases with different variants.

Serrated polyps of the colon are obligate precancerous condition, which can transform into cancer due to genetic aberrations. Serrated polyps are a heterogeneous group of formations with different ways of appearance and potential malignancy. They are divided into major subtypes: hyperplastic polyps, sessile serrated adenoma/polyp and traditional serrated adenoma.

The purpose of the study was the analysis of current data about mechanisms of formation and malignization of serrated colonic polyps.

The relationship between the localization of serrated polyps and their morphology was identified. Polyps located in the proximal colon are characterized by a more expressed degree of serration in the basal segment of crypts compared with polyps located in the distal part of the colon. The difference between the proximal and distal localization was confirmed by molecular genetic testing: the majority of proximal serrated polyps develops after BRAF mutations, and the majority of polyps with distal localization develops after a KRAS mutation.

It is known that a key role in the excessive proliferation and inhibition of apoptosis in the process of malignant transformation of serrated polyps is provided by the combination of different types of genome damage, both genetic and epigenetic. Molecular changes are already present in the early stages of cell dysplasia in serrated colon polyps, and their nature determines the malignant potential.

Conclusions. A thorough study of the molecular mechanisms of progression along the serrated pathway and transformation of serrated polyps in the CRC opens up prospects for the development of guidelines for patient management in order to prevent the development of serrated pathway cancers.

\section{Зубчасті поліпи як прекурсор розвитку раку товстої кишки: сучасний погляд і перспективи. Міні-огляд}

\section{O. Kузьо}

Своєчасна діагностика раннього раку товстої кишки є вкрай актуальним питанням сучасності, оскільки це захворювання посідає друге місце серед жінок і третє серед чоловіків у структурі онкологічної патології. Згідно з результатами останніх досліджень, рак товстої кишки слід розглядати як гетерогенну, мультифактор-зумовлену групу захворювань із різними варіантами перебігу.

Зубчасті поліпи товстої кишки є облігатним передраковим станом. У зв’язку з цим у світі активно вивчаються молекулярно-генетичні та імуноморфологічні аспекти їхнього злоякісного потенціалу. Сьогодні дослідники визнають: зубчасті поліпи товстої кишки можуть малігнізуватися шляхом послідовної трансформації, що зумовлена генетичними абераціями.

Мета роботи - аналіз сучасних даних щодо механізмів формування та малігнізації зубчастих поліпів товстої кишки.

Зубчасті поліпи є гетерогенною групою утворень, що мають різні шляхи розвитку та злоякісний потенціал. Згідно з останньою класифікацією ВООЗ, їх поділяють на основні підтипи: гіперпластичний поліп, сидяча зубчаста аденома/поліп і традиційна зубчаста аденома, хоча натепер тривають дискусії щодо їхніх діагностичних критеріїв і злоякісного потенціалу кожного з цих підтипів.

Виявлений зв'язок між локалізацією зубчастого поліпа та його морфологією. Гіперпластичні поліпи, що розташовані у проксимальній товстій кишці, характеризуються більш вираженим ступенем зубчастості в базальному сегменті крипт, ніж поліпи, котрі розташовані в дистальних відділах. Різниця між проксимальною та дистальною локалізацією також доведена за допомогою молекулярно-генетичного дослідження: більшість проксимальних зубчастих поліпів 3'являються після BRAF мутації, а більшість поліпів дистальної локалізації розвиваються після мутації KRAS. Відомо, що провідна роль у запуску надлишкової проліферації та пригноблення апоптозу у процесі злоякісного переродження зубчастих поліпів забезпечується комбінацією різних типів пошкодження геному як унаслідок порушення транскрипції генів, так і епігенетичних альтерацій. Молекулярні зміни наявні вже на ранній стадії клітинної дисплазії в зубчастих поліпах товстої кишки, а їх характер зумовлює їхній злоякісний потенціал.

Висновки. Детальне вивчення «зубчастого шляху» злоякісної трансформації поліпів товстої кишки в рак забезпечує майбутні перспективи щодо розробки стандартів із діагностики раннього раку товстої кишки та оцінювання його інвазивних властивостей.

Ключові слова: поліпи товстої кишки, рак товстої кишки, гістологія, мутація, аденокарцинома.

Патологія. - 2016. - № 2 (37). - С. 92-97

Зубчатые полипы как прекурсор развития рака толстой кишки: современный взгляд и перспективы. Мини-обзор

И. А. Кузьо

Своевременная диагностика раннего рака толстой кишки является крайне актуальной проблемой, так как данное заболевание занимает второе место среди женщин и третье среди мужчин в структуре онкологической патологии. Согласно последним 
данным, рак толстой кишки следует рассматривать в качестве гетерогенного, мультифактор-опосредованного семейства заболеваний с различными вариантами течения.

Зубчатые полипы толстой кишки являются облигатным предраковым состоянием. В связи с этим в мире активно изучаются молекулярно-генетические и иммуноморфологические аспекты их злокачественного потенциала. В настоящее время большинство исследователей признают, что зубчатые полипы толстой кишки путём последовательной трансформации, обусловленной генетическими аберрациями, могут трансформироваться в рак.

Цель работы - проведение анализа современных данных о механизмах формирования и малигнизации зубчатых полипов толстой кишки.

Зубчатые полипы представляют собой гетерогенную группу образований, отличных друг от друга, имеющих различные пути возникновения и потенциал озлокачествления. Согласно последней классификации ВОЗ, их разделяют на основные подтипы: гиперпластический полип, сидячая зубчатая аденома/полип и традиционная зубчатая аденома, хотя в настоящее время продолжается дискуссия относительно диагностических критериев и злокачественного потенциала каждого из этих подтипов.

Была выявлена связь между локализацией зубчатого полипа и его морфологией. Гиперпластические полипы, расположенные в проксимальной толстой кишке, характеризуются более выраженной степенью зубчатости в базальном сегменте крипт, чем полипы, расположенные в дистальных отделах. Различие между проксимальной и дистальной локализацией также подтверждено с помощью молекулярно-генетического исследования: большинство проксимальных зубчатых полипов развивается после BRAF мутации, а большинство полипов дистальной локализации развивается после мутации KRAS. Известно, что ключевая роль в запуске избыточной пролиферации и угнетения апоптоза в процессе злокачественного перерождения зубчатых полипов обеспечивается комбинацией различных типов повреждения генома как вследствие нарушения транскрипции генов, так и эпигенетических альтераций. Молекулярные изменения присутствуют уже на ранней стадии клеточной дисплазии в зубчатых полипах толстой кишки, а их характер предопределяет их злокачественный потенциал.

Выводы. Детальное изучение «зубчатого пути» злокачественной трансформации полипов толстой кишки в рак открывает перспективы по разработке стандартов по диагностике раннего рака толстой кишки и оценке его инвазивных свойств.

Ключевые слова: полипы толстой кишки, рак толстой кишки, гистология, мутация, аденокариинома.

Патология. - 2016. - № 2 (37). - С. 92-97

\section{Background}

Colorectal cancer $(\mathrm{CRC})$ takes the $3^{\text {rd }}$ place in men and the $2^{\text {nd }}$ place in women among all oncological diseases [1]. Given the extreme seriousness of this problem, the study of the features of the pathogenesis of this disease is gaining momentum. It was believed that CRC occurs from precursor benign polyp which makes possible the timely action to prevent it, but due to the new data received views on the origins of colorectal cancer have significantly changed [2].

First of all, the traditional postulate that «colon cancer develops from adenomatous polyp» through the traditional sequence of mutations has undergone the revision, as it has not been able to fully explain a significant proportion of cases of the colon cancer [3-5].

Special importance is given to the study of the genetic factors predisposition to the development of CRC. It became known that colon cancer can be the product of a mutation of several genes, each having sensitivity to environmental factors, such as smoking, physical inactivity, overweight and obesity, consumption of red meat and excessive alcohol consumption [6]. We know that with an increase in the life expectancy the risk of developing of CRC also increases, which is associated with an increased risk of CIMP-high BRAF-mutated CRC [7]. Recent data suggest that the probability of CRC is higher in family members of patients with BRAF-mutated CRC, than in patients without a family history [8].

The purpose of the study was the analysis of current data about mechanisms of formation and malignization of serrated colonic polyps.

Previously CRC was considered as a single disease, but recent data suggest that $\mathrm{CRC}$ is a heterogeneous set of diseases which are the product of various combinations of genetic events and epigenetic alterations [9]. WHO Classification of Tumours of the Digestive System lists the following conditions as precursor lesions of colorectal cancer: adenomas, serrated lesions, chronic inflammatory bowel disease, and hamartomatous polyps such as juvenile and Peutz-Jeghers polyps [10].

Lately the special attention is paid to the so-called serrated pathway of the pathogenesis of CRC, in which the key role is played by serrated colon polyps, as they are precursors of about $30 \%$ of CRC [4], from 15 to $20 \%$ of all carcinomas in the right parts of the colon arise from serrated formations and in the distal part their proportion is much smaller, [11], and serrated cancer of the proximal colon is associated with a better prognosis than cancers of the distal colon $[12,13]$.

In the past, all serrated lesions were regarded as hyperplastic polyp (HP). It was taken that they do not have a malignant potential, unlike the conventional adenoma, currently, however, a subgroup of these formations represents an alternative way of colorectal carcinogenesis [14]. During the studying of their molecular biology the heterogeneous group of polyps with saw-tooth crypts was considered as serrated polyps [15]. According to WHO serrated polyps are classified as hyperplastic polyps, sessile adenoma/polyps without or with cytological dysplasia, and traditional serrated adenomas [10].

\section{Classification of serrated polyps}

Over the past 30 years, our understanding of the nature of serrated colon formations dramatically changed due to colonoscopy [14]. In 1990 Longacre et al. prosed new term "serrated adenoma", which described adenomatous polyps with serrated crypts, is now referred to as TSA [16]. In 1996, Torlakovic and Snover coined the term "SSA/P" which is a pathological condition characterized by the location of 
polyps in the proximal colon with large dimensions and severe atypia of the nuclei [17]. In 2005 Snover and his colleagues formally recognized SSA/P and TSA as separate pathological conditions [18]. Currently, serrated polyps are considered to be formation, with 'saw-tooth' appearance of the colonic crypts [10]. This is probably due to the weakening of apoptosis and consequent aging of epithelial cells along the crypt [20].

It was noted that the spread of serrated polyps in the general population ranged from 13 to $40 \%$, according to the autopsy data [19] According to the prospective population-based study, it was noted that in $21 \%$ of subjects during the colonoscopy sole hyperplastic polyp was found [2].

Serrated polyps are a heterogeneous group of formations, which are different from each other macroscopically and histologically and have different ways of appearance and malignancy potential. According to the latest WHO classification, they are divided into major subtypes, which are defined as hyperplastic polyp (HP), sessile serrated adenoma/polyp (SSA/P) and traditional serrated adenoma (TSA), although currently there is an ongoing debate regarding the diagnostic criteria and the malignant potential of these polyps [10]. The method for differentiating of subgroups of serrated polyps is based on differences in the spread of proliferation zones [21].

The relationship between the localization of the serrated polyp and its morphology was identified. Hyperplastic polyps located in the proximal colon are characterized by a pronounced degree of serration in the basal segment of crypts than polyps located in the distal part [22]. The difference between the proximal and distal localization is also confirmed with genomic profiles: the majority of proximal serrated polyps developed after BRAF mutations, they are CIN-negative with high levels of MSI and CIMP. The majority of distal tumours develop after a KRAS mutation, they are CIN-positive with low levels of MSI and CIMP [23].

Hyperplastic polyps (HP)

Hyperplastic polyps are common, they make up 70-95\% of all serrated lesions or 25-30\% of resected large intestinal polyps [24]. They often occur in the left colon, particularly in the sigmoid colon and rectum, as diminutive, pale sessile lesions [25]. A precursor (predecessor) of both hyperplastic polyps (HP) and serrated neoplasia is metaplastic and serrated subtype of aberrant crypt foci (ACF).

Serrated polyps are associated with enhanced maturation of epithelial cells with their progression towards the surface and inhibition of apoptosis due to decreased expression of Fas receptor (CD 95) which is a transmembrane receptor of tumor necrosis factor (TNF) [26].

HP is characterized by straight crypts with a slight extension in their upper third without significant distortion of their shape and tend to have small sizes $(<5 \mathrm{~mm})$. Zones of enhanced proliferation are observed at the base of the crypts, and the cells mature toward the outer surface, as it used to be in normal glands $[21,27]$. HP is the most common type of gear polyps, their incidence is $80 \%$ to $95 \%$ of all gear polyps and $29 \%$ to $40 \%$ of all polyps. They are located in the distal part of the colon in $70 \%$ of cases [27]. Currently,
HP are histologically divided into microvesicular (MVHP), goblet cell-rich (GCHP) and mucin-poor (MPHP) HP according to WHO classification [10].

MVHP are characterized by the presence of single small mucin droplets in the cytoplasm and the serrated structure of the glands in the upper part of the crypts [28]. MVHP develop mainly in distal colon (74\%), while $26 \%$ of them are in the proximal part [29]. Of note that MVHP in proximal colon are characterized by the presence of BRAF mutations (70 \%) and their structure resembles histological SSA/P [30]. This mutation inhibits apoptosis as the colonocytes reach the epithelial surface, BRAF or KRAS is frequently mutated, and these mutations are most probably the initiating event in the majority of lesions [31] resulting in epithelial crowding, which is thought to be responsible for the serrated morphology. [21,24] Based on these data, MVHP are now considered to be precursors of the development of SSA/P [31].

In contrast, the GCHP consisted mainly of goblet cells congested with mucous and exhibit less marked serration of glands. They occur mainly in distal colon (>90\%) and typically have small size $(<5 \mathrm{~mm})$, are characterized by the presence of KRAS mutations (50\%) [14]. MPHP are characterized by the absence of mucus in the cytoplasm and it is very rare type of colon polyps which at the moment is poorly studied [24].

Sessile serrated adenoma/polyp (SSA/P)

$\mathrm{SSA} / \mathrm{P}$ are less common than HP and their incidence is 15 to $25 \%$ of all serrated polyps and 1,7 to $9 \%$ of all colon polyps [32]. They develop mainly in the proximal colon (75\%) and their size is greater than HP $(50 \%>5 \mathrm{~mm}, 15-20 \%>$ $10 \mathrm{~mm})$. SSA/P are difficult to detect by colonoscopy due to their flat shape, as compared with TSA which project into the lumen and have a bright red surface [32].

Previously it was difficult to differentiate SSA/P from HP due to the lack of clear diagnostic criteria. Histologically SSA/P resemble HP with prolonged increase of proliferation and serrated changes which propagate to the basal segment of the crypts [30]. SSA/P are characterized by dilatation of crypts and their branching horizontal growth with distorted crypt architecture, commonly with dilated, mucus-filled, L-shaped and T-shaped crypts with mature cells [33], the proliferation area asymmetrically distributed on the middle $1 / 3$ of crypts with the epithelium/stroma ratio often exceeded $50 \%$. Also the excessive secretion of mucus is usually observed, and this leads to the fact that formation has a distinctive "cap" of mucus. Nuclei are slightly increased, with clear nucleoli $[21,33]$. In addition, the morphological phenomenon of "pseudoinvasion" was noted, which is a protrusion of the crypts through muscle plate of mucosa [14].

It has been suggested that the SSA/P can develop from MVHP due to the apparent histological similarities and common association with BRAF mutation. However, the controversial evidence suggests that the main localization of SSA/P development is proximal colon, unlike MVHP which have a distal localization [24]. Recently Gonzalo with colleagues found that annexin A 10 can serve as a marker for distinguishing of SSA/P from MVHP [34]. 
Recently SSA/P were subdivided into time SSA/P without dysplasia and SSA/P with signs of cell dysplasia [34]. Also it was noted that in addition to conventional adenoma-like dysplasia the large cells with eosinophilic cytoplasm and elongated nuclei were observed in the dysplastic glands. This was considered as "serrated-type dysplasia" [14]. Molecular genetic studies have shown that they are characterized by BRAF mutation. Previously such conditions were called as 'mixed polyp', but according to the WHO these states should be referred to the SSA/P with cytological dysplasia. Obviously, SSA/P and TSA related to a high risk of CRC development. SSA/P in the proximal colon may progress to CRC due to a mutation BRAF gene with or without the phenomenon of microsatellite instability (MSI) [35].

Traditional serrated adenoma (TSA)

TSA is the least common form of serrated polyps, which is about $1 \%$ of the polyps and develops mainly in the rectum and sigmoid colon. Polypoid TSA are detected more frequently in men and they are less likely to progress to CRC as compared with women [36].

Histologically TSA is characterized by the villiform structure with the prevalence of cells with elongated nuclei and eosinophilic cytoplasm, nuclear stratification in 2-3 lines and the formation of false ectopic crypts [37]. In this case, increased proliferation area is an amount of small ectopic crypt-promoting villous [33]. A typical feature of the TSA is that ectopic proliferative crypts are perpendicular to the direction of growth villiform structures and is not in contact with the muscularis mucosae [33].

It was found that TSA is likely to progress into serrated carcinomas with a picture of mucinous and trabecular growth. Progression of such serrated carcinomas is more aggressive compared with carcinomas that have developed from the classic adenomas. It is assumed that the TSA development is associated with a mutation of KRAS and probably leads to the development of cancer by hypermethylation of DNA repair gene MGMT [14]. However, a recent study showed that the TSA have either KRAS (29-46\%) or BRAF (27-55\%) mutations [38], although it was believed that mutations of these genes are mutually exclusive. While TSA has an obvious malignant potential, mechanism of carcinogenesis remains to be studied yet.

Serrated-polyposis syndrome (SPS)

SPS is characterized by multiple serrated polyps including HP, SSA/P and TSA. According to WHO's data, clinical criteria for SPS are: (1) at least five serrated polyps in proximal colon, two of which are over $10 \mathrm{~mm}$ in diameter, (2) any number of serrated polyps in the proximal colon in a patient who has relative of first line with the serrated polyposis; or (3) 20 serrated polyps of all sizes of any colon localization [10]. Of note, patients with SPS are considered to be in a high risk group of CRC [39]. Moreover, these patients often have a family history of CRC [40], and it was reported about an increased relative risk of CRC in patients with the first line relatives with SRS. Thus, Boparai and his colleagues reported that in $35 \%$ of such cases (27 of 77) the SPS was found, and CRC was found in $6.5 \%$ (5 of 77) of those patients [41]. Carballal and colleagues recently reported that the presence of more than two SSA/P, which are more proximal to the splenic flexure, and one SSA/P in proximal colon with high-grade dysplasia were independent risk factors for $\mathrm{CRC}$ (incremental $\mathrm{OR}=2.95 \% \mathrm{CI}=1.22-3.24$, $\mathrm{p}=0.006$ ) in patients with SPS [42].

\section{Molecular features of the serrated pathway}

Colorectal neoplastic formations are not the result of a single mutation, but a consequence of different types of genomic damage, both a gene transcription and epigenetic alterations [43]. Among the genetic alterations two mutually exclusive categories of instability are identified. Chromosomal instability (CIN) develops after inactivating mutation of the tumor suppressor gene in the $5^{\text {th }}$ chromosome with a gap in Wnt signaling pathway and destruction of all or a part of the chromosomes. This leads to the activation of KRAS oncogenes or the inactivation of suppressor genes. An alternative is a microsatellite instability (MSI) which develops after inactivating mutations in the genes of DNA repair (mismatch repair) MLH1 and MSH2 and leads to multiple mutations and deletions. MSI is classed as high, low or absence (stability) [44].

Molecular changes are already present in the early stages of surface neoplasias and non-neoplasive formations, and their nature determines the clinical, morphological and biological characteristics of these formations [18].

The following predominant pathways for sporadic cancer development was proposed by Leggett and Whitehall: (1) the traditional pathway, which is characterized by chromosomal instability (CIN) and adenomatous polyposis coli (APC) mutation, which results in microsatellite-stable (MSS), CIMP-negative, BRAF and KRAS wild-type tumours, (2) the alternate pathway, in which either KRAS or APC mutation leads to the development of MSS CIMP-low tumours and (3) the serrated pathway, in which BRAF mutation can lead to colorectal cancer with MSI-high (MSI-H) CIMP-high (CIMP-H) or MSS CIMP-H phenotype [45].

The most prominent feature of the development of serrated polyps is mitogen activated protein kinase (MAPK) pathway, which is implemented through the mutation of BRAF oncogene and development of the CIMP. Violation of p53 is also involved in the development of serrated formations [46]. Very specific to serrated polyps is a BRAF and KRAS genes mutation. It was noted that frequently BRAF mutated in serrated aberrant crypt foci (62\%) [47], microvesicular HP (70-76 \%) [46], borderline SSA (80 \%) [48], SSA (61-100\%) [49] and SSA with cytological dysplasia or invasive cancer (64-100\%) [50]. The BRAF mutations is not typical goblet cells, but it was noted that KRAS mutated in $50 \%$ of cases of hyperplastic polyps [46]. Conversely, the development of cancer from serrated polyps in the proximal colon is characterized with mutation of BRAF, CIMP and with or without MSI [18].

\section{Conclusions}

1. CRC should be considered as a heterogeneous multifactorial family of diseases with different course variants due to the set of combinations of genetic events and epigenetic alterations. 
2. Special attention is paid to the serrated pathway of cancer, where the key role is played by serrated polyps of the colon, which are characterized by crypts glandular serration.

3. The genomic profile and malignant potential of serrated colon polyps are described by defining of the status of CIN, MSI, CIMP and the initial mutation in KRAS, BRAF, and APC oncogene.
4. A thorough study of the molecular mechanisms of progression along the serrated pathway and transformation of serrated polyps in the CRC opens up prospects for the development of guidelines for patient management in order to prevent the development of serrated pathway cancers.

Conflict of interests: authors have no conflict of interest to declare.

\section{References}

1. Jemal, A., Bray, F., Center, M., Ferlay, J., Ward, E., \& Forman, D. (2011). Global cancer statistics. CA: A Cancer Journal For Clinicians, 61(2), 69-90. doi: 10.3322/caac.20107.

2. Forsberg, A., Kjellström, L., Agréus, L., Nixon Andreasson, A., Nyhlin, H., Talley, N., \& Björck, E. (2012). Prevalence of colonic neoplasia and advanced lesions in the normal population: a prospective population-based colonoscopy study. Scandinavian Journal Of Gastroenterology, 47(2), 184-190. doi: 10.3109/00365521.2011.647062.

3. Huth, L., Jäkel, J., \& Dahl, E. (2014). Molecular Diagnostic Applications in Colorectal Cancer. Microarrays, 3(3), 168-179. doi: 10.3390/microarrays3030168.

4. Singh, R., Zorrón Cheng Tao Pu, L., Koay, D., \& Burt, A. (2016). Sessile serrated adenoma/polyps: Where are we at in 2016? World Journal Of Gastroenterology, 22(34), 7754. doi: 10.3748/wjg.v22.i34.7754.

5. Schell, M., Yang, M., Teer, J., Lo, F., Madan, A., Coppola, D. et al. (2016). A multigene mutation classification of 468 colorectal cancers reveals a prognostic role for APC. Nature Communications, 7, 11743. doi: 10.1038/ncomms11743.

6. Anderson, J., Rangasamy, P., Rustagi, T., Myers, M., Sanders, M., Vaziri, H. et al. (2011). Risk Factors for Sessile Serrated Adenomas. Journal Of Clinical Gastroenterology, 45(8), 694-699. doi: 10.1097/MCG.0b013e318207f3cf.

7. Buchanan, D., Sweet, K., Drini, M., Jenkins, M., Win, A., Gattas, M. et al. (2010). Phenotypic diversity in patients with multiple serrated polyps: a genetics clinic study. International Journal Of Colorectal Disease, 25(6), 703-712. doi: 10.1007/ s00384-010-0907-8.

8. Wish, T., Hyde, A., Parfrey, P., Green, J., Younghusband, H., Simms, M. et al. (2010). Increased Cancer Predisposition in Family Members of Colorectal Cancer Patients Harboring the p.V600E BRAF Mutation: a Population-Based Study. Cancer Epidemiology Biomarkers \& Prevention, 19(7), 1831-1839. doi: 10.1158/1055-9965.EPI-10-0055.

9. Samadder, N., Vierkant, R., Tillmans, L., Wang, A., Weisenberger, D., Laird, P. et al. (2013). Associations Between Colorectal Cancer Molecular Markers and Pathways With Clinicopathologic Features in Older Women. Gastroenterology, 145(2), 348-356.e2. doi: 10.1053/j.gastro.2013.05.001.

10. (2015). UEG Week 2015 Poster Presentations. United European Gastroenterology Journal, 3(5 Suppl), 146-687. doi: 10.1177/2050640615601623.

11. Anderson, J., Swede, H., Rustagi, T., Protiva, P., Pleau, D., Brenner, B. et al. (2012). Aberrant crypt foci as predictors of colorectal neoplasia on repeat colonoscopy. Cancer Causes \& Control, 23(2), 355-361. doi: 10.1007/s10552-011-9884-7.

12. Murcia, O., Juárez, M., Hernández-Illán, E., Egoavil, C., Giner-Calabuig, M., Rodríguez-Soler, M., Jover, R. (2016). Serrated colorectal cancer: Molecular classification, prognosis, and response to chemotherapy. World Journal Of Gastroenterology, 22(13), 3516-3530. doi: 10.3748/wjg. v22.i13.3516.

13. Nagtegaal, I. \& Hugen, N. (2015). The Increasing Relevance of Tumour Histology in Determining Oncological Outcomes in Colorectal Cancer. Curr Colorectal Cancer Rep, 11(5), 259-266. doi: 10.1007/s11888-015-0280-7.
14. Rex, D., Ahnen, D., Baron, J., Batts, K., Burke, C., Burt, R. et al. (2012). Serrated Lesions of the Colorectum: Review and Recommendations From an Expert Panel. The American Journal Of Gastroenterology, 107(9), 1315-1329. doi: 10.1038/ ajg.2012.161.

15. Shussman, N. \& Wexner, S. (2014). Colorectal polyps and polyposis syndromes. Gastroenterology Report, 2(1), 1-15. doi: $10.1093 /$ gastro/got041.

16. Longacre, T. \& Fenoglio-Preiser, C. (1990). Mixed Hyperplastic Adenomatous Polyps/Serrated Adenomas. The American Journal Of Surgical Pathology, 14(6), 524-537. doi: 10.1097/00000478-199006000-00003.

17. Torlakovic, E. \& Snover, D. (1996). Serrated adenomatous polyposis in humans. Gastroenterology, 110(3), 748-755. doi: 10.1053/gast.1996.v110.pm8608884.

18. Snover, D., Jass, J., Fenoglio-Preiser, C., \& Batts, K. (2005). Serrated Polyps of the Large Intestine: A Morphologic and Molecular Review of an Evolving Concept. American Journal Of Clinical Pathology, 124(3), 380-391. doi: 10.1309/V2EPTPLJ-RB3F-GHJL.

19. Cekodhima, G., Cekodhima, A., Beqiri, A., Alimehmeti, M., \& Sulo, G. (2016). Demographic And Histopathological Characteristics Of Colorectal Polyps: A Descriptive Study Based On Samples Obtained From Symptomatic Patients. Slovenian Journal Of Public Health, 55(2). doi: 10.1515/sjph2016-0016.

20. Carragher, L., Snell, K., Giblett, S., Aldridge, V., Patel, B., Cook, S. et al. (2010). V600E Braf induces gastrointestinal crypt senescence and promotes tumour progression through enhanced $\mathrm{CpG}$ methylation of p16 INK4a. EMBO Molecular Medicine, 2(11), 458-471. doi: 10.1002/emmm.201000099.

21. Snover, D. (2011). Update on the serrated pathway to colorectal carcinoma. Human Pathology, 42(1), 1-10. doi: 10.1016/j. humpath.2010.06.002.

22. Kahi, C., Li, X., Eckert, G., \& Rex, D. (2012). High colonoscopic prevalence of proximal colon serrated polyps in average-risk men and women. Gastrointestinal Endoscopy, 75(3), 515-520. doi: 10.1016/j.gie.2011.08.021.

23. Sinicrope, F., Shi, Q., Smyrk, T., Thibodeau, S., Dienstmann, R., Guinney, J. et al. (2015). Molecular Markers Identify Subtypes of Stage III Colon Cancer Associated With Patient Outcomes. Gastroenterology, 148(1), 88-99. doi: 10.1053/j. gastro.2014.09.041.

24. Bettington, M., Walker, N., Clouston, A., Brown, I., Leggett, B., \& Whitehall, V. (2013). The serrated pathway to colorectal carcinoma: current concepts and challenges. Histopathology, 62(3), 367-386. doi: 10.1111/his.12055.

25. Rex, D., Ahnen, D., Baron, J., Batts, K., Burke, C., Burt, R. et al. (2012). Serrated Lesions of the Colorectum: Review and Recommendations From an Expert Panel. The American Journal Of Gastroenterology, 107(9), 1315-1329. doi: 10.1038/ ajg.2012.161.

26. Fujimori, Y., Fujimori, T., Imura, J., Sugai, T., Yao, T., Wada, R. et al. (2012). An assessment of the diagnostic criteria for sessile serrated adenoma/polyps: SSA/Ps using image processing software analysis for Ki67 immunohistochemistry. Diagnostic Pathology, 7(1). doi: 10.1186/1746-15967-59. 
27. Crockett, S., Snover, D., Ahnen, D., \& Baron, J. (2015). Sessile Serrated Adenomas: An Evidence-Based Guide to Management. Clinical Gastroenterology And Hepatology, 13(1), 11-26.e1. doi: 10.1016/j.cgh.2013.10.035.

28. Lin, Y., Chiu, H., Lee, Y., Shun, C., Wang, H., \& Wu, M. (2014). Hyperplastic polyps identified during screening endoscopy: Reevaluated by histological examinations and genetic alterations. Journal Of The Formosan Medical Association, 113(7), 417-421. doi: 10.1016/j.jfma.2012.07.030.

29. Yuyucu Karabulut, Y., Savas, B., Kursun, N., \& Ensar, A. (2014). Serrated lesions of the appendix: Do they differ from their colorectal counterparts?. The Turkish Journal Of Gastroenterology, 25(1), 29-34. doi: 10.5152/tjg. 2014.4056.

30. Rau, T., Agaimy, A., Gehoff, A., Geppert, C., Jung, K., Knobloch, K. et al. (2014). Defined morphological criteria allow reliable diagnosis of colorectal serrated polyps and predict polyp genetics. Virchows Archiv, 464(6), 663-672. doi: 10.1007/ s00428-014-1569-7.

31. Obuch, J., Pigott, C., \& Ahnen, D. (2015). Sessile Serrated Polyps: Detection, Eradication, and Prevention of the Evil Twin. Current Treatment Options In Gastroenterology, 13(1), 156-170. doi: 10.1007/s11938-015-0046-y.

32. Rosty, C., Hewett, D., Brown, I., Leggett, B., \& Whitehall, V. (2012). Serrated polyps of the large intestine: current understanding of diagnosis, pathogenesis, and clinical management. Journal Of Gastroenterology, 48(3), 287-302. doi: 10.1007/ s00535-012-0720-y.

33. Ko, H., Harpaz, N., McBride, R., Cui, M., Ye, F., Zhang, D. et al. (2015). Serrated colorectal polyps in inflammatory bowel disease. Mod Pathol, 28(12), 1584-1593. doi: 10.1038/ modpathol.2015.111.

34. Gonzalo, D., Lai, K., Shadrach, B., Goldblum, J., Bennett, A., Downs-Kelly, E. et al. (2013). Gene expression profiling of serrated polyps identifies annexin A10 as a marker of a sessile serrated adenoma/polyp. The Journal Of Pathology, 230(4), 420-429. doi: 10.1002/path.4200.

35. Minarikova, P., Benesova, L., Halkova, T., Belsanova, B., Suchanek, S., Cyrany, J. et al. (2016). Longitudinal molecular characterization of endoscopic specimens from colorectal lesions. World Journal Of Gastroenterology, 22(20), 4936. doi: 10.3748/wjg.v22.i20.4936.

36. Saiki, H., Nishida, T., Yamamoto, M., Hayashi, S., Shimakoshi, H., Shimoda, A., et al. (2016). Frequency of coexistent carcinoma in sessile serrated adenoma/polyps and traditional serrated adenomas removed by endoscopic resection. Endosc Int Open, 04(04), E451-E458. doi: 10.1055/s-0042-103239.

37. Zhao, X., Zhan, Q., Xiang, L., Wang, Y., Wang, X., Li, A., \& Liu, S. (2014). Clinicopathological Characteristics of Laterally Spreading Colorectal Tumor. Plos ONE, 9(4), e94552. doi: 10.1371/journal.pone.0094552.

38. Fu, X., Qiu, Y., \& Zhang, Y. (2014). Screening, management and surveillance for the sessile serrated adenomas/polyps. Int J Clin Exp Pathol, 7(4), 1275-1285.
39. Miwata, T., Hiyama, T., Oka, S., Tanaka, S., Shimamoto, F., Arihiro, K., \& Chayama, K. (2013). Clinicopathologic features of hyperplastic/serrated polyposis syndrome in Japan. J Gastroenterol Hepatol, 28(11), 1693-1698. doi: 10.1111/ jgh.12307.

40. Kalady, M., Jarrar, A., Leach, B., LaGuardia, L., O’Malley, M., Eng, C., \& Church, J. (2011). Defining Phenotypes and Cancer Risk in Hyperplastic Polyposis Syndrome. Diseases Of The Colon \& Rectum, 54(2), 164-170. doi: 10.1007/ DCR.0b013e3181fd4c15.

41. Boparai, K., Reitsma, J., Lemmens, V., van Os, T., Mathus-Vliegen, E., Koornstra, J. et al. (2010). Increased colorectal cancer risk in first-degree relatives of patients with hyperplastic polyposis syndrome. Gut, 59(9), 1222-1225. doi: 10.1136/ gut.2009.200741.

42. Carballal, S., Rodríguez-Alcalde, D., Moreira, L., Hernández, L., Rodríguez, L., Rodríguez-Moranta, F. et al. (2015). Colorectal cancer risk factors in patients with serrated polyposis syndrome: a large multicentre study. Gut, gutjnl-2015-309647. doi: 10.1136/gutjnl-2015-309647.

43. Coghlin, C. \& Murray, G. (2015). Biomarkers of colorectal cancer: Recent advances and future challenges. PROTEOMICS - Clinical Applications, 9(1-2), 64-71. doi: 10.1002/ prca.201400082.

44. Geiersbach, K. \& Samowitz, W. (2011). Microsatellite Instability and Colorectal Cancer. Archives Of Pathology \& Laboratory Medicine, 135(10), 1269-1277. doi: 10.5858/ arpa.2011-0035-RA.

45. Leggett, B. \& Whitehall, V. (2010). Role of the Serrated Pathway in Colorectal Cancer Pathogenesis. Gastroenterology, 138(6), 2088-2100. doi: 10.1053/j.gastro.2009.

46. Spring, K., Zhao, Z., Karamatic, R., Walsh, M., Whitehall, V., Pike, T. et al. (2006). High Prevalence of Sessile Serrated Adenomas With BRAF Mutations: A Prospective Study of Patients Undergoing Colonoscopy. Gastroenterology, 131(5), 1400-1407. doi: 10.1053/j.gastro.2006.08.038.

47. Rosenberg, D., Yang, S., Pleau, D., Greenspan, E., Stevens, R., Rajan, T. et al. (2007). Mutations in BRAF and KRAS Differentially Distinguish Serrated versus Non-Serrated Hyperplastic Aberrant Crypt Foci in Humans. Cancer Research, 67(8), 3551-3554. doi: 10.1158/0008-5472. CAN-07-0343.

48. Mohammadi, M., Kristensen, M., Nielsen, H., Bonde, J., \& Holck, S. (2012). Qualities of sessile serrated adenoma/polyp/ lesion and its borderline variant in the context of synchronous colorectal carcinoma. Journal Of Clinical Pathology, 65(10), 924-927. doi:10.1136/jclinpath-2012-200803.

49. Carr, N., Tan, K., Mahajan, H., Hawkins, N., Ward, R., \& Nguyen, Q. (2009). Serrated and non-serrated polyps of the colorectum: their prevalence in an unselected case series and correlation of BRAF mutation analysis with the diagnosis of sessile serrated adenoma. Pathology, 41, 66. doi: 10.1097/01268031-200941001-00151.

\section{Information about author:}

Kuzo I. O., MMed, Postgraduate of the Department of Pathological Anatomy and Forensic Medicine, Zaporizhzhia State Medical University, Ukraine, E-mail: irinakuzyo@gmail.com.

\section{Відомості про автора:}

Кузьо І. О., магістр медицини, аспірант кафедри патологічної анатомії та судової медицини, Запорізький державний медичний університет, E-mail: irinakuzyo@gmail.com.

Сведения об авторе:

Кузьо И. А., магистр медицины, аспирант кафедры патологической анатомии и судебной медицины, Запорожский государственный медицинский университет, E-mail: irinakuzyo@gmail.com. 